\title{
Painful ophthalmoplaegia secondary to orbital myositis
}

\author{
Jeremy Hoffman, Tessa Fayers
}

Department of Ophthalmology, Surrey and Sussex Healthcare NHS Trust, Redhill, UK

\section{Correspondence to} Dr Jeremy Hoffman, jeremy.hoffman@nhs.net

Accepted 8 April 2015

\section{DESCRIPTION}

A 53-year-old man with rheumatoid arthritis presented with 1 week of progressive right-sided proptosis, diplopia and pain on eye movement, particularly when looking to the left. Examination demonstrated marked lid swelling, limited right elevation and dextroelevation with pain on adduction (figure 1A). The affected eye was injected and chemosed. There was no evidence of optic nerve compromise.

The patient was started on intravenous antibiotics for presumed orbital cellulitis. CT scan demonstrated thickening of the right lateral and superior rectus muscles and their tendinous insertions (figure 2). The patient was diagnosed with orbital myositis and treated with $80 \mathrm{mg}$ oral prednisolone. His symptoms improved almost immediately and $24 \mathrm{~h}$ later his ophthalmoplaegia and diplopia had resolved (figure 1B). He was discharged on a reducing corticosteroid regime.

Orbital myositis typically presents with painful diplopia. Pain is often worst when looking in the opposite direction to the action of the affected muscles, that is, when the muscle is stretched. It forms part of the idiopathic orbital inflammatory disease spectrum and is associated with systemic inflammatory diseases such as rheumatoid arthritis, sarcoidosis, Crohn's disease, systemic lupus erythematous and antineutrophil cytoplasmic antibody-associated vasculitis. ${ }^{1}$ The aetiology is unknown but recent research suggests an association with IgG4. ${ }^{2}$ Differential diagnoses include orbital cellulitis, orbital neoplasm, carotidcavernous fistulae, arteriovenous malformations and

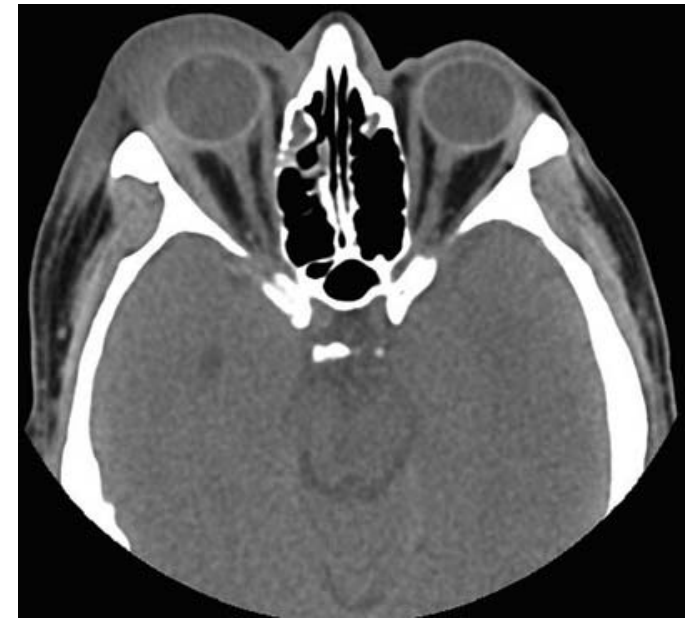

Figure 2 Axial section of CT of the head without contrast, demonstrating right lateral rectus thickening and thickening of the tendinous insertion.

thyroid eye disease. ${ }^{3}$ Since it can mimic orbital cellulitis, intravenous antibiotics are often started empirically; the lack of response may raise the suspicion of an alternative diagnosis. In contrast to orbital cellulitis, there is no fever, and white cell count and inflammatory markers are normal.

$\mathrm{CT} / \mathrm{MRI}$ is very useful to aid diagnosis. ${ }^{3}$ Treatment with high-dose corticosteroids usually produces a dramatic response. ${ }^{3}$ It can recur and refractory cases may require treatment with immunosuppressant drugs or radiotherapy. ${ }^{3}$
A

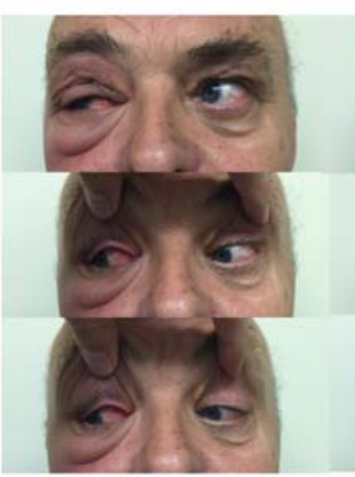

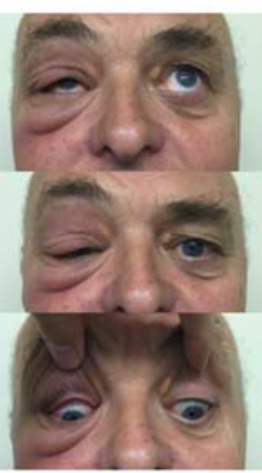

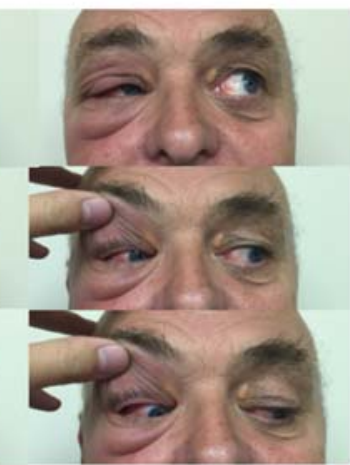

B

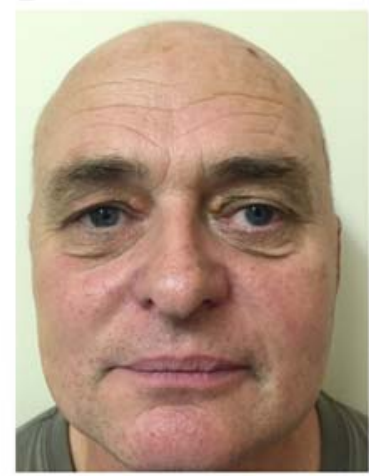

To cite: Hoffman J, Fayers T. BMJ Case Rep Published online: [please include Day Month Year] doi:10.1136/bcr-2015210106

Figure 1 (A) Colour photographs demonstrating the eye in the cardinal positions of gaze. Central image showing the eyes in primary position. There is moderate limitation of right eye dextroelevation and elevation, indicating impairment of the right lateral and superior recti muscles. Note: pain was maximal with eye movement in the opposite direction, that is, depression and laevodepression. There is marked right periorbital oedema, erythaema, conjunctival injection and chemosis. (B) Complete resolution of symptoms and signs 1 week following treatment with high-dose oral corticosteroids. 


\section{Learning points}

- Orbital myositis is an important differential for painful ophthalmoplaegia and can mimic orbital cellulitis.

- Prompt imaging (CT/MRI) is essential to aid in diagnosis and demonstrates thickening of the involved muscles and tendinous insertions, differentiating the condition from thyroid orbitopathy, which usually spares the tendons.

- Orbital myositis is typically exquisitely responsive to high-dose oral corticosteroids (1 $\mathrm{mg} / \mathrm{kg}$ prednisolone).

Twitter Follow Jeremy Hoffman at @idoctorhoff
Contributors $\mathrm{JH}$ wrote the first draft of the case report, initially treated the patient and took clinical photographs. TF was the educational supervisor and consultant in charge of the patient's care, oversaw the case report writing and provided help and support, and made a significant contribution to the final draft and figures.

Competing interests None declared.

\section{Patient consent Obtained.}

Provenance and peer review Not commissioned; externally peer reviewed.

\section{REFERENCES}

1 Lacey B, Chang W, Rootman J. Nonthyroid causes of extraocular muscle disease. Surv Ophthalmol 1999;44:187-213.

2 McNab AA, McKelvie P. IgG4-related ophthalmic disease. Part I: background and pathology. Ophthal Plast Reconstr Surg 2015;31:83-8.

3 Fraser CL, Skalicky SE, Gurbaxani A, et al. Ocular myositis. Curr Allergy Asthma Rep 2013;13:315-21.

Copyright 2015 BMJ Publishing Group. All rights reserved. For permission to reuse any of this content visit http://group.bmj.com/group/rights-licensing/permissions.

BMJ Case Report Fellows may re-use this article for personal use and teaching without any further permission.

Become a Fellow of BMJ Case Reports today and you can:

- Submit as many cases as you like

- Enjoy fast sympathetic peer review and rapid publication of accepted articles

- Access all the published articles

- Re-use any of the published material for personal use and teaching without further permission

For information on Institutional Fellowships contact consortiasales@bmjgroup.com

Visit casereports.bmj.com for more articles like this and to become a Fellow 